\title{
Nitrogen partitioning and isotopic fractionation in dairy cows consuming diets based on a range of contrasting forages
}

\author{
L. Cheng, ${ }^{\star 1}$ E. J. Kim, $†$ R. J. Merry, $†$ and R. J. Dewhurst ${ }^{\star} \dagger^{2}$ \\ *Faculty of Agriculture and Life Sciences, PO Box 84, Lincoln University, New Zealand \\ †Institute of Biological, Environmental and Rural Sciences, Aberystwyth University, Gogerddan, Aberystwyth SY23 3EB, United Kingdom
}

\begin{abstract}
Nine multiparous Holstein-Friesian cows (initially 97 $\mathrm{d}$ in milk), were used in a $3 \times 3$ lattice square design experiment with 4 -wk periods. All cows received $4 \mathrm{~kg} / \mathrm{d}$ concentrates and dietary treatments were based on silages offered ad libitum: perennial ryegrass (PRG); timothy (TIM); tall fescue (TF); red clover (RC); red clover/corn silage mixture [40/60 on a dry matter (DM) basis; RCC]; red clover/whole-crop oat silage mixture (40/60 on a DM basis; RCO); or red clover/whole-crop oat silage mixture (25/75 on a DM basis; ORC). The remaining treatments were based on $\mathrm{RCO}$ with feed intake restricted to the level of PRG (RCOr) or with a low protein concentrate (50/50 mixture of barley and molassed sugar beet pulp; RCOlp). Experiment objectives were to evaluate diet effects on $\mathrm{N}$ partitioning and $\mathrm{N}$ isotopic fractionation. Yields of milk and milk protein were consistently high for diets $\mathrm{RC}, \mathrm{RCC}$, and $\mathrm{RCO}$ and low for the diets based on poorly ensiled grass silages. Restriction of intake (RCOr) and inclusion of a higher proportion of whole-crop oat silage (ORC) and the low-protein concentrate (RCOlp) led to some loss of production. Diet had little effect on milk fat, protein, and lactose concentrations: low concentrations of milk protein and lactose reflect the restricted energy intakes for all treatments. The highest diet digestibilities were measured for RC and PRG, whereas increasing inclusion of the whole-crop oat silage $(0,60$, and $75 \%$ of forage $\mathrm{DM}$ ) led to a marked decrease in diet digestibility (0.717, 0.624, and $0.574 \mathrm{~g} / \mathrm{g}$, respectively). Urinary excretion of purine derivatives, an indicator for rumen microbial protein synthesis, was significantly higher for RCC than for TIM and TF. Nitrogen intake ranged between 359 and $626 \mathrm{~g} / \mathrm{d}$ (treatment means). Partitioning of $\mathrm{N}$ intake to feces and urine was closely related to $\mathrm{N}$ intake, although urinary $\mathrm{N}$ losses were less
\end{abstract}

Received August 27, 2010.

Accepted January 7, 2011.

${ }^{1}$ Corresponding author: long.cheng@lincolnuni.ac.nz

${ }^{2}$ Current address: Teagasc, Animal and Grassland Research and Innovation Centre, Grange, Dunsany, County Meath, Ireland. than predicted from $\mathrm{N}$ intake for the $60 / 40$ mixtures of cereal silage and red clover silage. The ${ }^{15} \mathrm{~N}$ content of milk, urine, and feces were all influenced by diet ${ }^{15} \mathrm{~N}$ content. Isotopic fractionation meant that feces and milk were enriched and urine was depleted in ${ }^{15} \mathrm{~N}$ relative to the diet. Significant relationships were observed between the extent of enrichment of urine, feces, and milk, suggesting some commonality in fractionation pathways. The trend for the lowest ${ }^{15} \mathrm{~N}$ enrichment in milk protein occurring in diets with low $\mathrm{N}$-use efficiency (milk N/feed N) was contrary to expectations, possibly because of endogenous contributions to milk protein or fractionation when dietary ammonia was incorporated into microbial protein.

Key words: dairy cow, nitrogen partitioning, nitrogen-15, isotopic fractionation

\section{INTRODUCTION}

Adequate dietary $\mathrm{N}$ is required to maximize production and profitability of dairying (Pfeffer and Hristov, 2005). It is important to feed the correct level and type of $\mathrm{N}$ to maximize conversion to product $\mathrm{N}$ and avoid increasing levels of potential $\mathrm{N}$ pollutants (urinary $\mathrm{N}$ leads to nitrates in water and nitrous oxide losses to the atmosphere). Nitrogen-use efficiency (NUE) is the efficiency of converting feed $\mathrm{N}$ into product $\mathrm{N}$ (in this case, milk) and can be assessed using the $\mathrm{N}$ balance (NB) technique. However, the NB technique is difficult to run and tends to overestimate $\mathrm{N}$ retention (MacRae et al., 1993; Spanghero and Kowalski, 1997).

Many previous studies have evaluated $\mathrm{N}$ partitioning with a wide range of diets, and overall relationships, such as that between $\mathrm{N}$ intake and urinary $\mathrm{N}$, have been described by assembling results from many studies (e.g., Kebreab et al., 2001; Huhtanen et al., 2008). Dewhurst et al. (2010) showed that these relationships might differ between diets based on ryegrass silage or mixtures of red clover and corn silages. The first objective of this study was a further evaluation of these relationships across diets based on grass silages from different species and mixtures of red clover silage with both corn silage and whole-crop oat silage. 
The second objective of this work was to develop simpler approaches to evaluate NUE, based on sampling that could be conducted without the need to house animals in metabolism stalls. Earlier work has used measurements of milk urea $\mathrm{N}$ for this purpose, and although problems with analytical methods have occurred (Broderick, 2003), strong correlations with urinary N (Nousiainen et al., 2004; Wattiaux and Karg, 2004) and NUE (Nousiainen et al., 2004) have been established. This work evaluated an alternative approach based on the phenomenon of $\mathrm{N}$ isotopic fractionation (isotopic discrimination), whereby some biochemical pathways discriminate between ${ }^{14} \mathrm{~N}$ and ${ }^{15} \mathrm{~N}$ as a result of the mass difference, resulting in differential enrichment of ${ }^{15} \mathrm{~N}$, with protein enriched and urine depleted relative to the diet (DeNiro and Epstein, 1981; Sutoh et al., 1987). Sick et al. (1997) demonstrated relationships between amino acid utilization and isotopic fractionation in the liver of rats fed different proteins. Sponheimer et al. (2003) provided preliminary evidence of increased enrichment of ${ }^{15} \mathrm{~N}$ in hair protein when ruminants were fed high protein diets. However, the situation is likely to be more complex in ruminants, because synthesis of protein by rumen microorganisms is an additional potential site of isotopic fractionation (Wattiaux and Reed, 1995). The wide range of $\mathrm{N}$ intake and the diversity of diets used in this study provide a good basis to evaluate the range of $\mathrm{N}$ isotopic fractionation in ruminants.

\section{MATERIALS AND METHODS}

This study used 9 multiparous Holstein-Friesian cows that were, on average, $97(\mathrm{SD}=6.8) \mathrm{DIM}$ and producing $24.3(\mathrm{SD}=4.87) \mathrm{kg} / \mathrm{d}$ of milk at the start of the experiment. Cows weighed $611(\mathrm{SD}=57.1), 609$ (SD $=51.7)$, and $597(\mathrm{SD}=63.1) \mathrm{kg}$ at the start of the 3 collection periods, respectively. Nine dietary treatments were evaluated in a $3 \times 3$ lattice square design (Cochran and Cox, 1950) experiment with 3 replicates; treatments were grouped 1 to 3,4 to 6 , and 7 to 9 for allocation to the squares. Animal measurements were made in the final wk of each 4 -wk period.

\section{Diets}

Pure stands of grasses, red clover, and corn were grown at Trawsgoed Research Farm $\left(52^{\circ} 25^{\prime} \mathrm{N}, 4^{\circ} 5^{\prime} \mathrm{W}\right)$, and winter oats were grown at Bow Street, Ceredigion $\left(52^{\circ} 26^{\prime} \mathrm{N}, 4^{\circ} 1^{\prime} \mathrm{W}\right)$. Perennial ryegrass (cultivar 'AberDart'), timothy (cultivar 'Promesse'), and tall fescue (cultivar 'Excella') were sown on April 20, 2004, and primary growth was harvested on August 5, 2004 (vegetative growth stage). Primary growth from red clover (cultivar 'Milvus') established in 2003 was harvested on May 19, 2004 (early bud growth stage). Slurry was applied to the grass areas before cultivation and the stands received $250 \mathrm{~kg} / \mathrm{ha}$ of $27-5-5$ (N-P-K) fertilizer on June 17, 2004. The red clover stand received a winter application of $250 \mathrm{~kg} / \mathrm{ha}$ of triple super phosphate and $250 \mathrm{~kg} / \mathrm{ha}$ of muriate of potash, but no $\mathrm{N}$ fertilizer. The grasses and red clover were wilted for $24 \mathrm{~h}$ and ensiled as round bales using Powerstart microbial inoculant (Genus Breeding Ltd., Nantwich, UK) applied according to the manufacturer's instructions. Whole-crop winter oats (cultivar 'Gerald') at the early-dough stage was precision-chopped and ensiled in a bunker silo, using Powerstart additive according to the manufacturer's instructions, on July 13, 2004. Corn (cultivar 'Calypso') at the mid-dough stage was precision-chopped and ensiled in bunker silos without the use of an additive.

All cows were fed a flat rate of $4 \mathrm{~kg} / \mathrm{d}$ of standard dairy concentrates, apart from 1 treatment that used a low-protein concentrate mix based on $2 \mathrm{~kg}$ of rolled barley and $2 \mathrm{~kg}$ of molassed sugar beet pulp. The dairy concentrate contained ( $\mathrm{g} / \mathrm{kg}$ on an air-dry basis): wheat (240), beans (200), rapeseed meal (175), corn distillers grains (150), soybean meal (50), palm kernel expeller (44), molasses (100), vegetable oil (21), and mineral/ vitamin premix (20). All cows received $100 \mathrm{~g} / \mathrm{d}$ of a mineral-vitamin mixture (Maxcare Phos $\mathrm{Mag}+\mathrm{Cu}-$ prex 5, Trouw (UK) Ltd., Northwich, UK) that contained calcium $13.5 \%$, sodium $10 \%$, magnesium $10 \%$, phosphorus $8 \%$, vitamin A 400,000 IU $/ \mathrm{kg}$, vitamin $\mathrm{D}_{3}$ $80,000 \mathrm{IU} / \mathrm{kg}$, vitamin E $800 \mathrm{IU} / \mathrm{kg}$, cobalt $160 \mathrm{mg} /$ $\mathrm{kg}$, manganese $4,000 \mathrm{mg} / \mathrm{kg}$, copper $2,500 \mathrm{mg} / \mathrm{kg}$, zinc $3,000 \mathrm{mg} / \mathrm{kg}$, iodine $400 \mathrm{mg} / \mathrm{kg}$, and selenium $35 \mathrm{mg} /$ $\mathrm{kg}$. The cows also had access to mineralized salt licks (Red Rockies, Rockies, Winsford, UK).

In addition to the concentrates, the dietary treatments were as follows: (1) perennial ryegrass silage ad libitum (PRG); (2) timothy silage ad libitum (TIM); (3) tall fescue silage ad libitum (TF); (4) red clover silage ad libitum (RC); (5) red clover silage/corn silage mixture (40\% red clover on a DM basis) ad libitum (RCC); (6) red clover silage/whole-crop oat silage mixture (40\% red clover on a DM basis) ad libitum (RCO); (7) red clover silage/whole-crop oat silage mixture $(25 \%$ red clover on a DM basis) ad libitum (ORC); (8) red clover silage/whole-crop oat silage mixture (40\% red clover on a DM basis), feed intake restricted to a level comparable to treatment 1 (RCOr); and (9) red clover silage/whole-crop oat silage mixture $(40 \%$ red clover on 
a DM basis) ad libitum, with $4 \mathrm{~kg} / \mathrm{d}$ of the low-protein concentrate mixture instead of standard concentrates (RCOlp).

\section{Animal Measurements}

This work was carried out under the authority of licenses issued by the UK Home Office. Feed intakes were recorded throughout the collection week, with amounts of forage offered adjusted to ensure 10\% refusals. Daily feed samples were composited over the collection week. Milk yields were recorded twice daily using mechanical milk meters (Tru-Test Ltd., Auckland, New Zealand) and samples for analysis taken from 4 consecutive milkings.

Separate total collections of feces and urine were made over 6 consecutive days using the externally applied urine separators described by Aston et al. (1998). Fecal and urine outputs lagged $1 \mathrm{~d}$ behind the measurement of intake. One day before collection commenced, a separator mounting (Velcro, Selectus Ltd., Stoke-onTrent, UK) was attached around the vulva and anus with contact adhesive (Evo Stik, Evode Ltd., Stafford, UK). On the following day, a urine collector fitted with $1.5 \mathrm{~m}$ of flexible hose was placed over the vulva and fastened to the separator mounting. Urine was retained in a 25 -L plastic container positioned in a drainage channel behind the cow. Urine was preserved during collection by adding $2 \mathrm{M} \mathrm{H}_{2} \mathrm{SO}_{4}$ into the container to maintain $\mathrm{pH}$ between 2 and 3 (approximately $2.8 \mathrm{~L} /$ cow per day, in 2 portions). To collect feces, a 350-mm-wide flexible plastic chute was secured by 4 elasticated straps attached to a girth band on the cow and supported with 2 straps fastened to a tubular framework at the rear of the stall. Fecal output was directed by the chute into a container suspended in the drainage channel. At the end of each collection period, bulked samples of feed, feces, and urine from individual cow were mixed, subsampled, and stored at $-20^{\circ} \mathrm{C}$. A further subsample of urine was diluted ( 1 volume urine plus 4 volumes of water) before freezing and used for analysis of purine derivatives.

\section{Analytical Methods}

Analytical methods used for feed have been described previously (Dewhurst et al., 2000). Urine was analyzed for $\mathrm{N}$ concentration using a Leco FP428 Nitrogen Analyzer (Leco Instruments (UK) Ltd., Stockport, UK), and feces were analyzed, without drying, using a Kjeldahl method. Milk samples were analyzed for fat, protein, and lactose concentrations using an infrared milk analyzer (NMR Central Laboratory, Somerset, UK). The diluted urine samples were analyzed for pu- rine derivatives (PD; allantoin plus uric acid) using the HPLC method of Dewhurst et al. (1996).

\section{Sample Preparation and ${ }^{15} \mathrm{~N}$ Measurements}

Samples of feeds, feces, and milk were freeze-dried and ground before $\mathrm{N}$ isotope measurements, and urine was analyzed in liquid form. Duplicates of each freeze-dried sample were weighed into $5 \times 8 \mathrm{~mm}$ tin capsules; the sample size was calculated to supply 100 to $200 \mu \mathrm{g}$ of nitrogen. Duplicate $10-\mu \mathrm{L}$ aliquots of each urine sample were pipetted into $5 \times 8 \mathrm{~mm}$ tin capsules containing an absorptive bed of Chromosorb W (Supelco, Bellefonte, PA). Nitrogen isotope measurements were made using a continuous-flow isotope ratio mass spectrometer (PDZ Europa Ltd., Crewe, UK) and results are expressed in delta units $\left(\delta^{15} \mathrm{~N}, \%\right)$; that is, the ${ }^{15} \mathrm{~N} /{ }^{14} \mathrm{~N}$ ratio in the test sample relative to the ${ }^{15} \mathrm{~N} /{ }^{14} \mathrm{~N}$ ratio in the standard (air). The ${ }^{15} \mathrm{~N}$ content of digested $\mathrm{N}$ was calculated according to Yoneyama et al. (1983):

$$
\begin{gathered}
\text { Digested } \delta^{15} \mathrm{~N}=\left[(\mathrm{N} \text { intake }) \times\left(\delta^{15} \mathrm{~N} \text { of feed }\right)\right. \\
\left.-(\mathrm{N} \text { output in feces }) \times\left(\delta^{15} \mathrm{~N} \text { of feces }\right)\right] / \\
{[\mathrm{N} \text { intake }-\mathrm{N} \text { output in feces }]}
\end{gathered}
$$

\section{Statistical Analysis}

The Genstat statistical package (version 10; Lawes Agricultural Trust, Rothamsted, UK) was used for ANOVA and linear regression analysis. Data were combined into single mean values for each period and dietary treatment. The overall ANOVA used the REML (linear mixed model) directive with cow + period as the random model and dietary treatment as the fixed model. Treatment means were compared using a Student-Newman-Keuls multiple comparison test.

\section{RESULTS}

\section{Feed Composition}

Feed analysis is presented in Table 1 . The mean CP content of sugar beet pulp and barley grain $(117.8 \mathrm{~g} /$ $\mathrm{kg}$ of DM) was less than half the $\mathrm{CP}$ content of the standard dairy concentrate $(251.2 \mathrm{~g} / \mathrm{kg}$ of $\mathrm{DM})$. The forages covered an extremely wide range of $\mathrm{CP}$ content (58 to $226 \mathrm{~g} / \mathrm{kg}$ of DM), as well as fermentation quality, with the grass silages having poor fermentation quality and very high levels of ammonia-N.

Table 2 provides calculated chemical composition for the overall diets. This shows the wide range of $\mathrm{CP}(130$ to $231 \mathrm{~g} / \mathrm{kg}$ of $\mathrm{DM}$ ) and starch (35 to $159 \mathrm{~g} / \mathrm{kg}$ of DM) concentrations across this set of diets, as well as 
Table 1. Chemical composition ( $\mathrm{g} / \mathrm{kg}$ of DM, unless stated otherwise) of the diet components used in this study ( $\mathrm{n}=3$ for each feed)

\begin{tabular}{|c|c|c|c|c|c|c|c|c|c|}
\hline Item & \multicolumn{9}{|c|}{ Diet component } \\
\hline $\mathrm{OM}$ & 919 & 869 & 976 & 867 & 891 & 878 & 888 & 949 & 960 \\
\hline $\mathrm{CP}$ & 251 & 103 & 133 & 226 & 185 & 194 & 206 & 98.8 & 57.5 \\
\hline $\mathrm{NDF}$ & 195 & 283 & 326 & 463 & 596 & 570 & 414 & 549 & 651 \\
\hline Starch & 178 & $\mathrm{ND}^{1}$ & 611 & ND & ND & ND & ND & 258 & 154 \\
\hline Ether extract & ND & ND & ND & 42.5 & 32.9 & 26.6 & 30.7 & 35.3 & 35.8 \\
\hline Acid hydrolysis ether extract & 55.8 & 9.1 & 31.5 & ND & ND & ND & ND & ND & ND \\
\hline $\mathrm{pH}$ & ND & ND & ND & 4.58 & 5.05 & 5.24 & 4.20 & 3.97 & 3.92 \\
\hline Ammonia-N (g/kg total-N) & ND & ND & ND & 165 & 206 & 186 & 97 & 95 & 85 \\
\hline Lactic acid & ND & ND & ND & 76.7 & 35.6 & 46.3 & 94.6 & 52.7 & 34.1 \\
\hline Acetic acid & ND & ND & ND & 31.1 & 41.3 & 35.2 & 30.3 & 20.1 & 7.7 \\
\hline
\end{tabular}

${ }^{1} \mathrm{ND}=$ not determined.

the high ammonia-N content of the grass silage-based diets.

\section{Feed Intake and Milk Production}

Feed intakes (Table 3) tended to be lower for TF and higher for the mixtures RCC and RCO. The yields of milk and milk protein (Table 3) were consistently high for diets RC, RCC, and RCO and low for the grass silage-based diets, particularly TIM and TF. Restriction of intake (RCOr) and inclusion of a higher proportion of whole-crop oat silage (ORC) led to some loss of production, whereas a greater loss of production occurred when the low-protein concentrate was offered (RCOlp). Diet had little effect on milk fat, protein and lactose concentrations.

\section{Diet Digestibility and Urinary Excretion of PD}

The highest diet digestibilities were measured for the PRG and RC diets, with values for TIM, TF, and RCC being only slightly lower (Table 4). Increasing inclusion of the whole-crop oat silage $(0,60$, and $75 \%$ of forage $\mathrm{DM}$ ) led to a marked decrease in diet digestibility $(0.717,0.624$, and $0.574 \mathrm{~g} / \mathrm{g}$, respectively). Urinary excretion of PD was similar for most treatments, but significantly higher for RCC than for TIM and TF (Table 4). Allantoin made up a constant $0.9(\mathrm{SD}=0.02) \mathrm{mol} /$ mol of PD excretion.

\section{Nitrogen Partitioning}

Nitrogen intakes ranged from 359 to $626 \mathrm{~g} / \mathrm{d}$ across the dietary treatments (Table 5) with a mean value of $495 \mathrm{~g} / \mathrm{d}$. The differences in $\mathrm{N}$ intake between treatments were strongly related to differences in dietary $\mathrm{CP}$ concentration (Table 2). Inclusion of an increasing proportion of whole-crop oat silage and the use of low protein concentrates both reduced $\mathrm{N}$ intake. Differences in fecal $\mathrm{N}$ (Table 5) closely mirrored differences in $\mathrm{N}$ intake. Numerically large differences in urinary $\mathrm{N}$ output were observed between the treatments (Table 5),

Table 2. Calculated chemical composition ( $\mathrm{g} / \mathrm{kg}$ of DM, unless stated otherwise) of the overall diets used in this study

\begin{tabular}{|c|c|c|c|c|c|c|c|c|c|}
\hline Item & \multicolumn{9}{|c|}{$\operatorname{Diet}^{1}$} \\
\hline $\mathrm{CP}$ & 231 & 198 & 207 & 214 & 169 & 159 & 160 & 130 & 134 \\
\hline Starch & 37.7 & 35.3 & 41.4 & 33.9 & 158 & 85.5 & 86.7 & 127 & 116 \\
\hline Ether extract & 45.3 & 37.5 & 33.4 & 35.5 & 36.6 & 36.6 & 36.8 & 40.3 & 29.8 \\
\hline Ammonia-N (\% of $\mathrm{N}$ intake) & 13.0 & 16.5 & 14.3 & 7.9 & 7.9 & 7.4 & 7.3 & 7.2 & 7.0 \\
\hline
\end{tabular}


Table 3. Effects of dietary treatments on feed intake, milk yield, and milk composition

\begin{tabular}{|c|c|c|c|c|c|c|c|c|c|c|c|}
\hline \multirow[b]{2}{*}{ Item } & \multicolumn{9}{|c|}{ Dietary treatment ${ }^{1}$} & \multirow[b]{2}{*}{ SED } & \multirow[b]{2}{*}{ Significance } \\
\hline & PRG & TIM & $\mathrm{TF}$ & $\mathrm{RC}$ & $\mathrm{RCC}$ & $\mathrm{RCO}$ & $\mathrm{RCOr}$ & RCOlp & ORC & & \\
\hline Silage DM intake $(\mathrm{kg} / \mathrm{d})$ & 12.9 & 13.9 & 11.4 & 14.7 & 15.7 & 15.5 & 14.4 & 13.7 & 13.6 & 1.24 & $\dagger$ \\
\hline Total DM intake $(\mathrm{kg} / \mathrm{d})$ & 16.3 & 17.4 & 14.9 & 18.2 & 19.1 & 19.0 & 17.8 & 17.2 & 17.1 & 1.24 & $\dagger$ \\
\hline Milk yield $(\mathrm{kg} / \mathrm{d})$ & $24.4^{\mathrm{bc}}$ & $22.3^{\mathrm{abc}}$ & $19.5^{\mathrm{a}}$ & $26.1^{\mathrm{c}}$ & $27.2^{\mathrm{c}}$ & $26.1^{\mathrm{c}}$ & $25.2^{\mathrm{bc}}$ & $20.5^{\mathrm{ab}}$ & $24.8^{\mathrm{bc}}$ & 1.58 & $* *$ \\
\hline Milk fat $(\%)$ & 4.02 & 3.86 & 4.29 & 3.95 & 3.89 & 4.04 & 3.88 & 4.39 & 4.16 & 0.224 & NS \\
\hline Milk protein (\%) & 3.03 & 2.96 & 2.99 & 3.03 & 3.06 & 3.05 & 2.91 & 3.13 & 3.01 & 0.096 & NS \\
\hline Milk lactose $(\%)$ & $4.61^{\mathrm{ab}}$ & $4.48^{\mathrm{a}}$ & $4.56^{\mathrm{ab}}$ & $4.67^{\mathrm{ab}}$ & $4.66^{\mathrm{ab}}$ & $4.75^{\mathrm{b}}$ & $4.66^{\mathrm{ab}}$ & $4.68^{\mathrm{ab}}$ & $4.67^{\mathrm{ab}}$ & 0.060 & $*$ \\
\hline Milk fat $(\mathrm{g} / \mathrm{d})$ & 988 & 854 & 829 & 1,013 & 1,050 & 1,064 & 970 & 882 & 1,009 & 71.8 & * \\
\hline Milk protein $(\mathrm{g} / \mathrm{d})$ & $730^{\text {bcd }}$ & $657^{\mathrm{abc}}$ & $577^{\mathrm{a}}$ & $775^{\mathrm{cd}}$ & $816^{\mathrm{d}}$ & $799^{\mathrm{d}}$ & $731^{\mathrm{bcd}}$ & $639^{\mathrm{ab}}$ & $739^{\mathrm{bcd}}$ & 38.9 & ** \\
\hline Milk lactose (g/d) & $1,128^{\mathrm{bcd}}$ & $1,010^{\mathrm{abc}}$ & $885^{\mathrm{a}}$ & $1,217^{\mathrm{cd}}$ & $1,271^{\mathrm{d}}$ & $1,246^{\mathrm{cd}}$ & $1,176^{\mathrm{bcd}}$ & $958^{\mathrm{ab}}$ & $1,163^{\text {bcd }}$ & 78.0 & $* *$ \\
\hline
\end{tabular}

${ }^{\mathrm{a}-\mathrm{d}}$ Means with different superscripts are significantly different at the $5 \%$ confidence level (Student-Newman-Keuls test).

${ }^{1}$ Diets based on perennial ryegrass silage (PRG); timothy silage (TIM); tall fescue silage (TF); red clover silage (RC); mixture of red clover and corn silages (40/60 on a DM basis; $\mathrm{RCC}$ ); mixture of red clover and whole-crop oat silages (40/60 on a DM basis; RCO); RCO with restriction on forage intake (RCOr); RCO with low protein concentrate (RCOlp); or a mixture of red clover and whole-crop oat silages (25/75 on a DM basis; ORC)

$\dagger P<0.1 ; * P<0.05 ; * * P<0.01 ; \mathrm{NS}=$ not significant.

Table 4. Effects of dietary treatments on the digestibility of DM, OM, and N, as well as urinary excretion of purine derivatives

\begin{tabular}{|c|c|c|c|c|c|c|c|c|c|c|c|}
\hline \multirow[b]{2}{*}{ Item } & \multicolumn{9}{|c|}{ Dietary treatment ${ }^{1}$} & \multirow[b]{2}{*}{ SED } & \multirow[b]{2}{*}{ Significance } \\
\hline & PRG & TIM & $\mathrm{TF}$ & $\mathrm{RC}$ & $\mathrm{RCC}$ & $\mathrm{RCO}$ & $\mathrm{RCOr}$ & RCOlp & ORC & & \\
\hline DM digestibility (g/g) & $0.724^{\mathrm{e}}$ & $0.666^{\mathrm{cd}}$ & $0.682^{\mathrm{d}}$ & $0.717^{\mathrm{e}}$ & $0.687^{\mathrm{d}}$ & $0.624^{\mathrm{b}}$ & $0.648^{\mathrm{bc}}$ & $0.637^{\mathrm{bc}}$ & $0.574^{\mathrm{a}}$ & 0.0104 & $* * *$ \\
\hline OM digestibility $(\mathrm{g} / \mathrm{g})$ & $0.744^{\mathrm{d}}$ & $0.681^{\mathrm{c}}$ & $0.689^{\mathrm{c}}$ & $0.730^{\mathrm{d}}$ & $0.695^{\mathrm{c}}$ & $0.627^{\mathrm{b}}$ & $0.651^{\mathrm{b}}$ & $0.639^{\mathrm{b}}$ & $0.579^{\mathrm{a}}$ & 0.0119 & $* * *$ \\
\hline $\mathrm{N}$ digestibility $(\mathrm{g} / \mathrm{g})$ & 0.706 & 0.701 & 0.703 & 0.691 & 0.674 & 0.692 & 0.672 & 0.619 & 0.613 & 0.0276 & $*$ \\
\hline Urinary allantoin $(\mathrm{mmol} / \mathrm{d})$ & $260^{\mathrm{ab}}$ & $201^{\mathrm{a}}$ & $200^{\mathrm{a}}$ & $259^{\mathrm{ab}}$ & $312^{\mathrm{b}}$ & $275^{\mathrm{ab}}$ & $254^{\mathrm{ab}}$ & $261^{\mathrm{ab}}$ & $276^{\mathrm{ab}}$ & 23.4 & ** \\
\hline Urinary uric acid $(\mathrm{mmol} / \mathrm{d})$ & 33.2 & 25.3 & 26.1 & 29.4 & 33.2 & 26.5 & 27.8 & 28.6 & 31.2 & 2.37 & $\dagger$ \\
\hline Urinary purine derivatives $(\mathrm{mmol} / \mathrm{d})$ & $292^{\mathrm{ab}}$ & $227^{\mathrm{a}}$ & $226^{\mathrm{a}}$ & $290^{\mathrm{ab}}$ & $344^{\mathrm{b}}$ & $300^{\mathrm{ab}}$ & $282^{\mathrm{ab}}$ & $289^{\mathrm{ab}}$ & $308^{\mathrm{ab}}$ & 24.4 & $*$ \\
\hline
\end{tabular}

a ${ }^{\mathrm{a}-\mathrm{Means}}$ with different superscripts are significantly different at the $5 \%$ confidence level (Student-Newman-Keuls test).

${ }^{1}$ Diets based on perennial ryegrass silage (PRG); timothy silage (TIM); tall fescue silage (TF); red clover silage (RC); mixture of red clover and corn silages (40/60 on a DM basis

$\lesssim \mathrm{RCC}$ ); mixture of red clover and whole-crop oat silages (40/60 on a DM basis; RCO); RCO with restriction on forage intake (RCOr); RCO with low protein concentrate (RCOlp);

$\subseteq$ or a mixture of red clover and whole-crop oat silages $(25 / 75$ on a DM basis; ORC)

$\stackrel{0}{\perp} \dagger P<0.1 ;{ }^{*} P<0.05 ;{ }^{* *} P<0.01 ;{ }^{* * *} P<0.001$ 
ranging from values that were almost as low as milk $\mathrm{N}$ for diets RCOlp and ORC to values that were over 2.5 times milk $\mathrm{N}$ for the grass silage-based diets. On average, cows retained $21.8 \mathrm{~g}$ of $\mathrm{N} / \mathrm{d}$ and this was not significantly different across treatments owing to the large variation in these estimates.

\section{N-Isotopic Fractionation}

Results of ${ }^{15} \mathrm{~N}$ analysis in feed, feces, milk, and urine, as well as the calculated ${ }^{15} \mathrm{~N}$ content in digested $\mathrm{N}$ are shown in Table 6 . Highly significant differences were observed in feed ${ }^{15} \mathrm{~N}$ and, although feces and milk were generally enriched and urine was depleted relative to the diet, the diet pattern was still evident in their ${ }^{15} \mathrm{~N}$ content. Because of the diet differences, we have also presented deviations of milk and urine ${ }^{15} \mathrm{~N}$ content from dietary (or digested $\mathrm{N}$ ) values. These latter values facilitate comparison between diets of the amount of isotopic fractionation within our cows.

Weak but significant relationships were observed between $\left(\delta^{15} \mathrm{~N}\right.$ urine $-\delta^{15} \mathrm{~N}$ feed $)$ and $\left(\delta^{15} \mathrm{~N}\right.$ fecal $-\delta^{15} \mathrm{~N}$ feed) $\left(\mathrm{r}^{2}=0.26 ; P<0.01 ; \mathrm{n}=27\right)$ and between $\left(\delta^{15} \mathrm{~N}\right.$ urine $-\delta^{15} \mathrm{~N}$ feed $)$ and $\left(\delta^{15} \mathrm{~N}\right.$ milk $-\delta^{15} \mathrm{~N}$ feed $)\left(\mathrm{r}^{2}=\right.$ $0.29 ; P<0.01 ; \mathrm{n}=27)$. A much stronger relationship was observed between $\left(\delta^{15} \mathrm{~N}\right.$ fecal $-\delta^{15} \mathrm{~N}$ feed $)$ and $\left(\delta^{15} \mathrm{~N}\right.$ milk $-\delta^{15} \mathrm{~N}$ feed $)\left(\mathrm{r}^{2}=0.73 ; P<0.001 ; \mathrm{n}=27\right)$.

\section{DISCUSSION}

\section{Feed Composition}

The grass silages used in this study were wilted to 250 to $330 \mathrm{~g}$ of $\mathrm{DM} / \mathrm{kg}$, which partially restricted fermentation. Nonetheless, the fermentation quality of these silages was poor, with $\mathrm{pH}$ greater than 4.5, appreciable levels of acetic and butyric acids, as well as a particularly high level of protein breakdown (ammonia-N). The quality of the grass silages was poor considering that an inoculant providing high numbers of homofermentative lactic acid bacteria was used. The most likely explanation is a shortfall in the amount of water-soluble carbohydrate (WSC) available to fuel the rapid fermentation and $\mathrm{pH}$ decline required to stabilize the silages, as even inoculant lactic acid bacteria cannot function effectively when substrate is limiting. Low WSC values are common in timothy and fescue grasses (McDonald et al., 1991) and high $\mathrm{N}$ fertilizer use also leads to high N and low WSC contents (White, 1973). Unfortunately, the substrate limitation hypothesis cannot be confirmed because values for herbage WSC content are not available, although the high $\mathrm{N}$ content of the grass silages is consistent with this effect.
The red clover and corn silages were more typical of these materials in the United Kingdom, with $\mathrm{pH}$ and ammonia- $\mathrm{N}$ relatively low for the red clover silage (Dewhurst et al., 2003) and the corn silage starch content relatively high (Kirkland and Patterson, 2006). Wholecrop oat silage is not common in the United Kingdom; the material used for this study contained more NDF and starch and less CP than spring-sown oat silages used in Canada (Khorasani et al., 1993, 1997). The starch content of the current whole-crop oat silage was similar to the early dough-stage silage prepared by Wallsten et al. (2010).

\section{Milk Production and Composition}

The relatively low replication in this study meant that numerically large differences in DM intake were only evident as an overall trend $(P<0.1)$. Nonetheless, the lowest intake for TF silage is consistent with the high content of NDF and particularly poor fermentation characteristics of this silage. The high intakes for RCC and RCO were also consistent with the high quality of the component forages, as well as previous experience with mixtures of red clover and corn silage (Dewhurst et al., 2010). These differences between dietary treatments were more evident in yields of milk and milk components. The low yields for grass silage-based diets reflect the low feed intake rather than diet digestibility, which was generally high for these diets.

Milk protein and lactose contents were low for all treatments, particularly TIM and TF. This suggests a general lack of dietary energy (Sutton, 1989) because of the low level of concentrates offered, the low intakes of the grass silages, and the low digestibility of the wholecrop oat silage.

\section{Diet Digestibility and Urinary Excretion of PD}

The forage proportion of DM intake only ranged from 0.767 (TF) to 0.819 (RCC), despite the use of a flat rate of concentrates and ad libitum forages. Consequently, the diet digestibilities largely reflect differences between the forages. Digestibilities were highest for the grass and red clover silage, reflecting their comparative immaturity as evidenced by relatively high protein and low NDF contents (Dewhurst et al., 2003). The digestibility of red clover-based diets was reduced slightly by inclusion of corn silage, and substantially by the inclusion of whole-crop oat silage. Despite containing $154 \mathrm{~g}$ of starch $/ \mathrm{kg}$ of $\mathrm{DM}$, this silage was relatively mature with $651 \mathrm{~g}$ of NDF/ $\mathrm{kg}$ of DM; the digestibility of NDF in mature whole-crop oats is low (Wallsten et al., 2010). 
Table 5. Effects of dietary treatments on nitrogen intake and outputs $(\mathrm{g} / \mathrm{d})$

\begin{tabular}{|c|c|c|c|c|c|c|c|c|c|c|c|}
\hline Item & \multicolumn{9}{|c|}{ Dietary treatment ${ }^{1}$} & SED & Significance \\
\hline $\mathrm{N}$ intake & $605^{\mathrm{c}}$ & $547^{\mathrm{bc}}$ & $494^{\mathrm{b}}$ & $626^{\mathrm{c}}$ & $512^{\mathrm{b}}$ & $473^{\mathrm{b}}$ & $464^{\mathrm{b}}$ & $379^{\mathrm{a}}$ & $359^{\mathrm{a}}$ & 36.4 & $* * *$ \\
\hline Milk N & $115^{\mathrm{bcd}}$ & $103^{\mathrm{abc}}$ & $90.5^{\mathrm{a}}$ & $121^{\mathrm{cd}}$ & $128^{\mathrm{d}}$ & $125^{\mathrm{d}}$ & $115^{\mathrm{bcd}}$ & $100^{\mathrm{ab}}$ & $116^{\text {bcd }}$ & 6.10 & $* *$ \\
\hline Urine N & $302^{\mathrm{c}}$ & $259^{c}$ & $256^{\mathrm{c}}$ & $275^{\mathrm{c}}$ & $181^{\mathrm{b}}$ & $148^{\mathrm{ab}}$ & $162^{\mathrm{ab}}$ & $117^{\mathrm{a}}$ & $122^{\mathrm{a}}$ & 18.8 & $* * *$ \\
\hline Retained N & 21 & 16 & 13 & 35 & 44 & 51 & 39 & 17 & -21 & 29.8 & NS \\
\hline
\end{tabular}

${ }^{\mathrm{a}-\mathrm{d}}$ Means with different superscripts are significantly different at the $5 \%$ confidence level (Student-Newman-Keuls test).

${ }^{1}$ Diets based on perennial ryegrass silage (PRG); timothy silage (TIM); tall fescue silage (TF); red clover silage (RC); mixture of red clover and corn silages (40/60 on a DM basis; RCC); mixture of red clover and whole-crop oat silages (40/60 on a DM basis; RCO); RCO with restriction on forage intake (RCOr); RCO with low protein concentrate (RCOlp); or a mixture of red clover and whole-crop oat silages $(25 / 75$ on a DM basis; ORC).

$\dagger P<0.1 ;{ }^{* *} P<0.01 ;{ }^{* * *} P<0.001 ; \mathrm{NS}=$ not significant.

Tas and Susenbeth (2007) confirmed the strong relationship between urinary PD excretion and the duodenal flow of purine bases, which are mainly derived from rumen microorganisms. Urinary excretion of $\mathrm{PD}$ (mmol/d) was high for diet RCC and low for TIM and TF. It seems likely that variation in the level and composition of feed intake affects rumen microbial yield through the availability of substrate for rumen fermentation. However, variation also existed in PD excretion per kilogram of DM intake, indicative of variation in microbial energetic efficiency. The low values for TIM, $\mathrm{TF}$, and RCOr may be related to low rumen passage rates increasing rumen residence time and so the proportion of energy used for microbial maintenance (Agricultural and Food Research Council, 1992).

\section{Nitrogen Partitioning}

Although the mean $\mathrm{N}$ retention in this study $(21.8$ $\mathrm{g} / \mathrm{d})$ was close to the corrected mean value $(20.6 \mathrm{~g} / \mathrm{d})$ reported by Spanghero and Kowalski (1997), it implies lean tissue growth around $0.5 \mathrm{~kg} / \mathrm{d}$, which seems unlikely for cows in early to mid lactation. This discrepancy illustrates the difficulties of the NB technique and its tendency to overestimate $\mathrm{N}$ retention, even when well conducted.

This study generated a very wide range of $\mathrm{N}$ intakes across divergent diets and so is useful to evaluate relationships between $\mathrm{N}$ intake and $\mathrm{N}$ outputs. Taking individual values, no significant relationship was observed between $\mathrm{N}$ intake and milk $\mathrm{N}$ output. A highly significant increase was observed in fecal $\mathrm{N}$ in response to increasing $\mathrm{N}$ intake, with approximately $21 \%$ of additional $\mathrm{N}$ partitioned to feces (equation [1]):

$$
\begin{aligned}
& \text { fecal } \mathrm{N}(\mathrm{g} / \mathrm{d})=54.3(\mathrm{SE}=13.6)+0.21 \\
& (\mathrm{SE}=0.0270) \mathrm{N} \text { intake }(\mathrm{g} / \mathrm{d}) \\
& \left(\mathrm{n}=27 ; \mathrm{r}^{2}=0.70 ; P<0.001\right) .
\end{aligned}
$$

\section{Nitrogen Isotopic Fractionation}

The $\delta^{15} \mathrm{~N}$ of grass silage-based diets was higher than that of the diets based on red clover silage (mean 5\%

Approximately $60 \%$ of additional $\mathrm{N}$ intake was partitioned to urine (equation [2]):

$$
\begin{gathered}
\text { urinary } \mathrm{N}(\mathrm{g} / \mathrm{d})=-91.4(\mathrm{SE}=38.0)+0.59 \\
(\mathrm{SE}=0.0753) \mathrm{N} \text { intake }(\mathrm{g} / \mathrm{d}) \\
\left(\mathrm{n}=27 ; \mathrm{r}^{2}=0.70 ; P<0.001\right) .
\end{gathered}
$$

The relationship between $\mathrm{N}$ intake and urinary $\mathrm{N}$ was explored further by comparing treatment means with the relationships established by Kebreab et al. (2001) and Huhtanen et al. (2008). Most of the studies in these meta-analyses used grass silage-based diets. Kebreab et al. (2001) suggested some curvilinearity in the relationship, with a slightly higher proportion of $\mathrm{N}$ apportioned to urine at higher $\mathrm{N}$ intakes. These relationships and the current results were in good overall agreement (Figure 1).

Urinary $\mathrm{N}$ was greater than predicted for $\mathrm{TF}$, suggesting that low energy intake, low microbial protein synthesis, or both led to some inefficiency with this diet. Urinary $\mathrm{N}$ was less than predicted for $\mathrm{RC}$ and the diets based on 40/60 mixtures of red clover silage with corn silage or whole-crop oat silage. This is consistent with earlier results with red clover silage (Dewhurst et al., 2003) or mixtures of red clover silage and corn silage (Dewhurst et al., 2010). Moving N excretion from urine to feces is valuable because urine $\mathrm{N}$ is more likely to lead to ammonia volatilization and nitrate leaching (Castillo et al., 2000). Interestingly, the reduced urinary $\mathrm{N}$ relative to prediction was not evident for the low protein diets ORC and RCOlp where urea recycling would be a more important component of $\mathrm{N}$ utilization. 
difference). Although a small $\mathrm{N}$ isotopic fractionation was associated with $\mathrm{N}$ fixation by legumes (Ledgard, 1989), considerable variation exists in ${ }^{15} \mathrm{~N}$ content of feeds, particularly between farms, that is not yet explained (Schwertl et al., 2005). These differences mean that it is most useful to evaluate the ${ }^{15} \mathrm{~N}$ content of milk, feces, and urine using deviations from feed values. In agreement with the earlier study with cattle (Sutoh et al., 1987), feces (Sutoh: 0.8\%; this study: 1.5\%) and milk (Sutoh: 2.1\% ; this study: 2.9\%) were enriched in ${ }^{15} \mathrm{~N}$ relative to the diet, whereas urine was depleted (Sutoh: $-4.8 \%$; this study $-3.3 \%$ ).

Highly significant $(P<0.001)$ relationships were observed between $\delta^{15} \mathrm{~N}$ in feed and feces (Figure 2), as well as between $\delta^{15} \mathrm{~N}$ in feed and digested $\mathrm{N}$ (Figure 3). The intercepts for these relationships were significantly different $(P<0.001)$ from zero and slopes were significantly different from $1(P<0.001)$. This effect may be related to isotopic fractionation during digestion and absorption or an effect of the endogenous contribution to feces. If the endogenous material has a high $\delta^{15} \mathrm{~N}$, it would exert a greater effect on the overall $\delta^{15} \mathrm{~N}$ of feces from the red clover silage-based diets, which had a lower $\delta^{15} \mathrm{~N}$. It is interesting that the effect was similar for diets $\mathrm{RC}$ and $\mathrm{RCO}$, despite the latter containing $25 \%$ less CP. If this effect is related to endogenous fecal $\mathrm{N}$, the implication is that endogenous fecal $\mathrm{N}$ must have been higher for diet RC than for RCO. This would be contrary to the general observation that endogenous $\mathrm{N}$ increases with increasing DM intake (Tamminga et al., 1995).

After correcting for differences in feed values, significant correlations still existed between the ${ }^{15} \mathrm{~N}$ content of milk, feces, and urine, although the correlations between milk and urine and feces and urine were only modest $\left(r^{2}=0.29\right.$ and 0.26 , respectively), suggesting that different sources of isotopic fractionation may have been operating. A much stronger relationship between $\left(\delta^{15} \mathrm{~N}\right.$ fecal $-\delta^{15} \mathrm{~N}$ feed $)$ and $\left(\delta^{15} \mathrm{~N}\right.$ milk $-\delta^{15} \mathrm{~N}$ feed $)$ was observed $\left(r^{2}=0.73\right.$; Figure 4$)$. The most likely cause of this relationship is the common effect of ${ }^{15} \mathrm{~N}$ from body reserves - the endogenous component of feces (Ouellet et al., 2002) and the contribution of body protein to milk protein (Wilson et al., 1988).

The second major objective of this work was to evaluate the relationships between $\mathrm{N}$ isotope fractionation and NUE. It is expected that fractionation of $\mathrm{N}$ isotopes during transamination and deamination reactions leads to increased ${ }^{15} \mathrm{~N}$ enrichment in protein when NUE is low (Sick et al., 1997). Sponheimer et al. (2003) provided preliminary evidence for enrichment of ${ }^{15} \mathrm{~N}$ in protein (in that case, hair) when ruminants were offered a high protein diet, which would be expected to result in lower NUE. However, we observed an opposite 


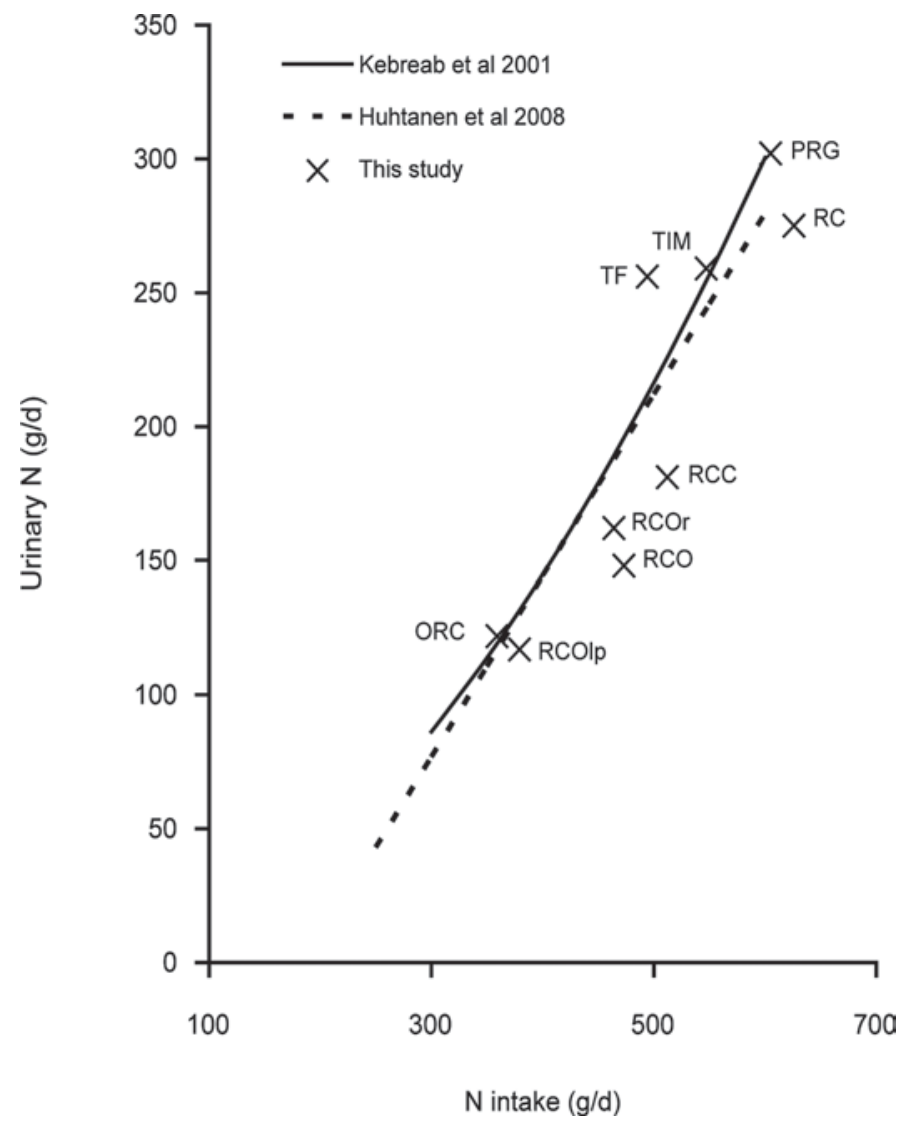

Figure 1. Relationship between $\mathrm{N}$ intake (g/d) and urinary $\mathrm{N}$ output $(\mathrm{g} / \mathrm{d})$ in this experiment and relationships established by previous reviews of the literature (Kebreab et al., 2001; Huhtanen et al., 2008). Values are adjusted treatment means for dietary treatments from this study: $\mathrm{PRG}=$ perennial ryegrass silage; $\mathrm{TIM}=$ timothy silage; $\mathrm{TF}=$ tall fescue silage; $\mathrm{RC}=$ red clover silage; $\mathrm{RCC}=$ mixture of red clover and corn silages (40/60 on a DM basis); $\mathrm{RCO}=$ mixture of red clover and whole-crop oat silages (40/60 on a DM basis); $\mathrm{RCOr}=\mathrm{RCO}$ with restriction on forage intake; $\mathrm{RCOlp}=\mathrm{RCO}$ with low protein concentrate; $\mathrm{ORC}=$ mixture of red clover and whole-crop oat silages $(25 / 75$ on a DM basis).

trend in this study, with the lowest ${ }^{15} \mathrm{~N}$ enrichment in milk protein for diets with low NUE (TIM and TF).

Several possible causes exist for the absence of the expected relationship between $\mathrm{N}$ isotope fractionation and NUE. It is anticipated that there would be proportionately more synthesis of microbial protein from ammonia, as opposed to amino acids, for the grass silagebased diets because of their high content of ammonia and low starch content (Bryant, 1973). Incorporation of ammonia into rumen bacteria results in depletion of ${ }^{15} \mathrm{~N}$ in bacteria (Wattiaux and Reed, 1995), which leads in turn to lower ${ }^{15} \mathrm{~N}$ in milk protein. The particularly low ${ }^{15} \mathrm{~N}$ enrichment of milk from TF and TIM groups appears difficult to explain given that the urinary excretion of purine derivatives suggests low microbial protein synthesis for these diets. However, these findings

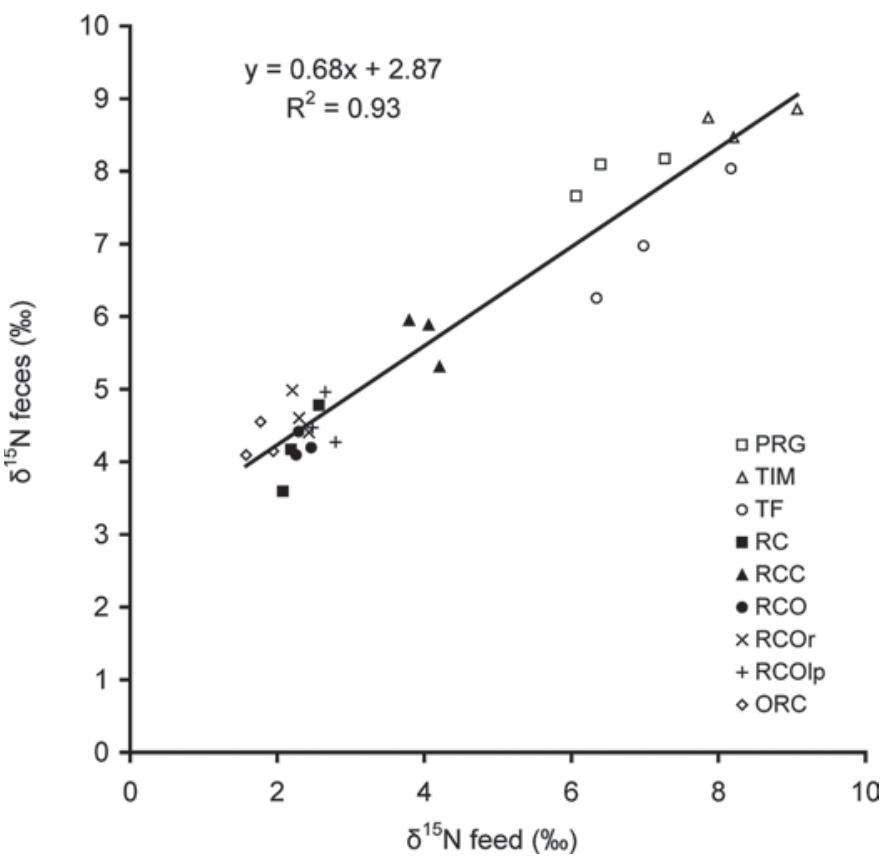

Figure 2. Relationship between $\delta^{15} \mathrm{~N}$ in feed $(\%)$ and $\delta^{15} \mathrm{~N}$ in feces $(\%)$ for individual observations. Diets were based on perennial ryegrass silage (PRG); timothy silage (TIM); tall fescue silage (TF); red clover silage (RC); mixture of red clover and corn silages $(40 / 60$ on a DM basis; RCC); mixture of red clover and whole-crop oat silages (40/60 on a DM basis; RCO); RCO with restriction on forage intake (RCOr); RCO with low protein concentrate (RCOlp); or a mixture of red clover and whole-crop oat silages (25/75 on a DM basis; ORC). Delta units $\left(\delta^{15} \mathrm{~N}\right)$ describe the ${ }^{15} \mathrm{~N} /{ }^{14} \mathrm{~N}$ ratio in the test sample relative to the ${ }^{15} \mathrm{~N} /{ }^{14} \mathrm{~N}$ ratio in the standard (air) and are expressed per mil $(\%)$.

are not necessarily inconsistent because a reduction in microbial growth yield (microbial protein produced per mole of ATP) has been associated with increased synthesis from ammonia (Maeng and Baldwin, 1976).

A second potential issue is the effect of $\delta^{15} \mathrm{~N}$ in mobilized body reserves contributing to milk protein (Wilson et al., 1988); the wide range in the $\delta^{15} \mathrm{~N}$ of feeds used in this study could easily have biased $\delta^{15} \mathrm{~N}$ for milk and urine. Differences in the use of $\mathrm{N}$ fertilizer between crops may have affected the distribution of $\mathrm{N}$ isotopes within diet components (DeNiro and Epstein, 1981), which may further complicate the interpretation of differences in $\mathrm{N}$-isotope fractionation between diets.

\section{CONCLUSIONS}

This study confirmed the high intake and milk production potential of diets based on red clover silage, as well as mixtures of red clover silage and cereal silage. A wide range of $\mathrm{N}$ intake was recorded across this study, and around 21 and $60 \%$ of incremental $\mathrm{N}$ was excreted in feces and urine, respectively. Inclusion of $60 \%$ cereal 


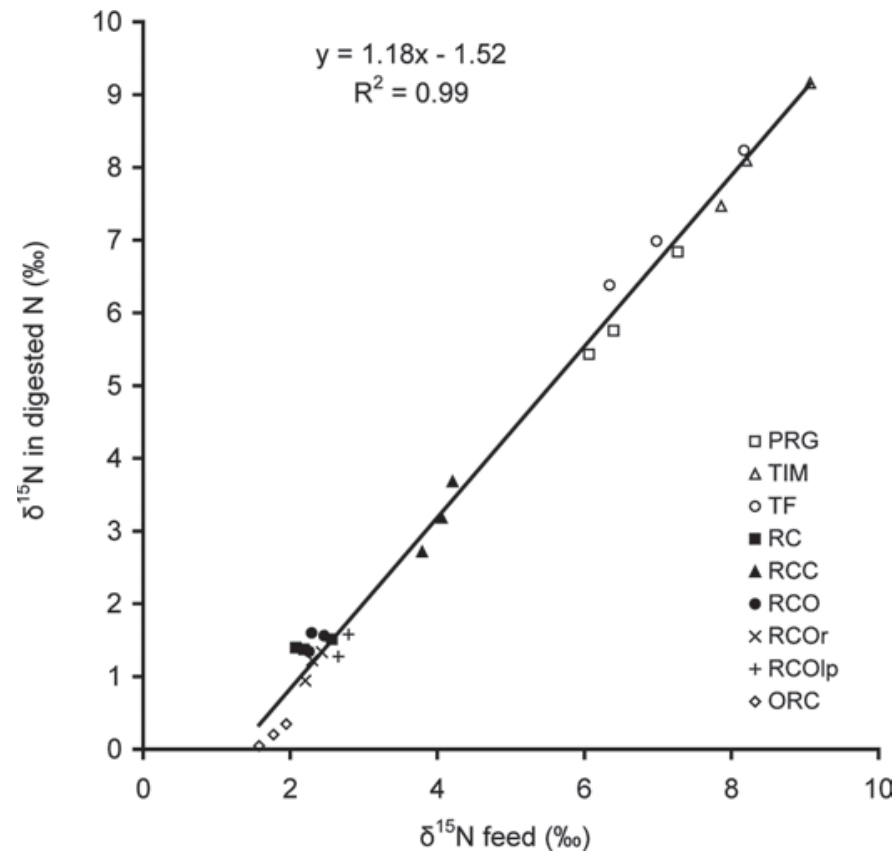

Figure 3. Relationship between $\delta^{15} \mathrm{~N}$ in feed $(\%)$ and $\delta^{15} \mathrm{~N}$ in digested N (\%) for individual observations. Diets were based on perennial ryegrass silage (PRG); timothy silage (TIM); tall fescue silage $(\mathrm{TF})$; red clover silage (RC); mixture of red clover and corn silages (40/60 on a DM basis; RCC); mixture of red clover and whole-crop oat silages (40/60 on a DM basis; RCO); RCO with restriction on forage intake (RCOr); $\mathrm{RCO}$ with low protein concentrate (RCOlp); or a mixture of red clover and whole-crop oat silages (25/75 on a DM basis; ORC). Delta units $\left(\delta^{15} \mathrm{~N}\right)$ describe the ${ }^{15} \mathrm{~N} /{ }^{14} \mathrm{~N}$ ratio in the test sample relative to the ${ }^{15} \mathrm{~N} /{ }^{14} \mathrm{~N}$ ratio in the standard (air) and are expressed per mil $(\%)$.

silage in a forage mixture was confirmed as an effective way to obtain the production benefits of red clover silage without excessive urinary $\mathrm{N}$ losses. Urinary $\mathrm{N}$ output was close to predictions from $\mathrm{N}$ intake based on literature reviews, although lower levels were recorded for the red clover silage-based diet as well as for the 40/60 red clover silage/cereal silage-based diets. This is an important effect because urine $\mathrm{N}$ is more likely to cause environmental pollution than fecal $\mathrm{N}$. We were not able to confirm a relationship between $\mathrm{N}$-isotopic fractionation and NUE for these diets. The N-isotopic fractionation approach appears unsuited for comparisons of NUE in short-term changeover designs where the contribution of ${ }^{15} \mathrm{~N}$ from body reserves may complicate relationships, or for diets containing different amounts of ammonia-N.

\section{ACKNOWLEDGMENTS}

The financial support of the Department for Environment, Food and Rural Affairs (United Kingdom; $\mathrm{N}$ partitioning study) and Ministry of Agriculture and Fisheries (New Zealand; stable isotope work) is

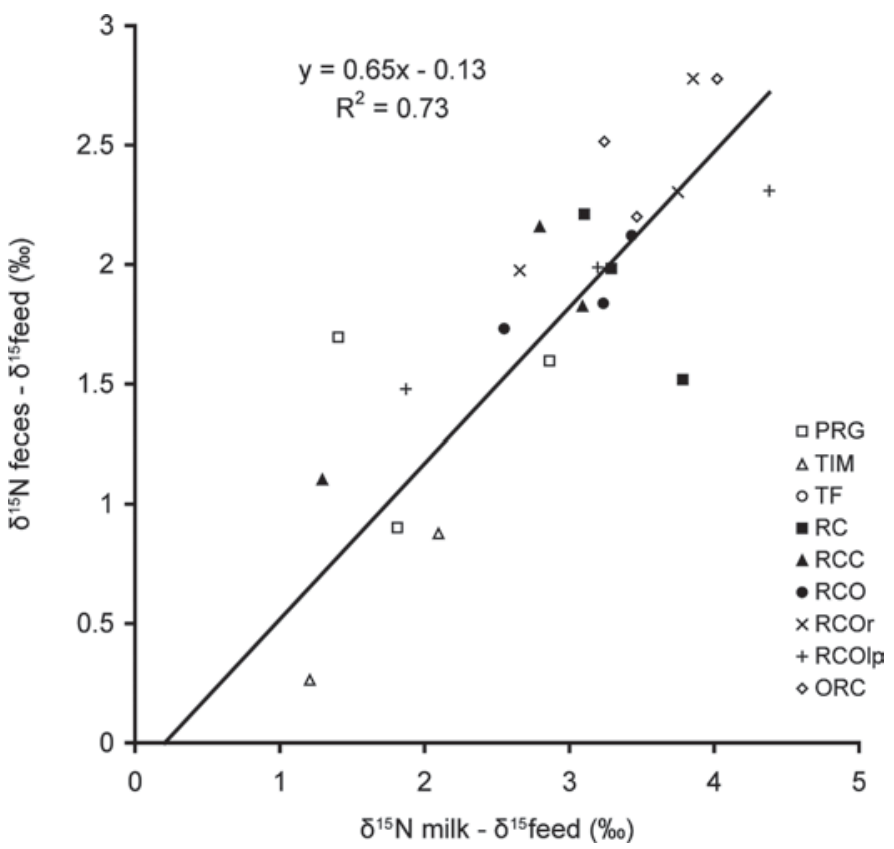

Figure 4. Relationship between $\delta^{15} \mathrm{~N}$ feces $-\delta^{15} \mathrm{~N}$ feed $(\%)$ and $\delta^{15} \mathrm{~N}$ milk $-\delta^{15} \mathrm{~N}$ feed $(\%)$ for individual observations. Diets were based on perennial ryegrass silage (PRG); timothy silage (TIM); tall fescue silage (TF); red clover silage (RC); mixture of red clover and corn silages (40/60 on a DM basis; RCC); mixture of red clover and whole-crop oat silages (40/60 on a DM basis; RCO); RCO with restriction on forage intake (RCOr); $\mathrm{RCO}$ with low protein concentrate (RCOlp); or a mixture of red clover and whole-crop oat silages $(25 / 75$ on a DM basis; ORC). Delta units $\left(\delta^{15} \mathrm{~N}\right)$ describe the ${ }^{15} \mathrm{~N} /{ }^{14} \mathrm{~N}$ ratio in the test sample relative to the ${ }^{15} \mathrm{~N} /{ }^{14} \mathrm{~N}$ ratio in the standard (air) and are expressed per mil $(\%)$.

gratefully acknowledged. The authors acknowledge the skilled technical assistance of the staff of Trawsgoed Research Farm and the analytical and nutrition research laboratories in Aberystwyth (United Kingdom). We are also grateful to Roger Cresswell and the stable isotope laboratory at Lincoln University (New Zealand) for help and advice with the ${ }^{15} \mathrm{~N}$ analysis.

\section{REFERENCES}

Agricultural and Food Research Council. 1992. AFRC Technical Committee on Responses to Nutrients. 9. Nutritive Requirements of Ruminant Animals: Protein. Nutr. Abstr. Rev. Ser. B 62:787-835.

Aston, K., W. J. Fisher, A. B. McAllan, M. S. Dhanoa, and R. J. Dewhurst. 1998. Supplementation of grass silage-based diets with small quantities of concentrates: Strategies for allocating concentrate crude protein. Anim. Sci. 67:17-26.

Broderick, G. A. 2003. Effects of varying dietary protein and energy levels on the production of lactating dairy cows. J. Dairy Sci. $86: 1370-1381$

Bryant, M. P. 1973. Nutritional requirements of the predominant rumen celluloytic bacteria. Fed. Proc. 32:1809-1813.

Castillo, A. R., E. Kebreab, D. E. Beever, and J. France. 2000. A review of efficiency and nitrogen utilization in lactating dairy cows and its relationship with environmental pollution. J. Anim. Feed Sci. 9:1-32.

Cochran, W. G., and G. M. Cox 1950. Experimental Designs. Wiley, New York, NY. 
DeNiro, M. J., and S. Epstein. 1981. Influence of diet on the distribution of nitrogen isotopes in animals. Geochim. Cosmochim. Acta 45:341-351.

Dewhurst, R. J., L. J. Davies, and E. J. Kim. 2010. Effects of mixtures of red clover and maize silages on the partitioning of dietary nitrogen between milk and urine by dairy cows. Animal 4:732-738.

Dewhurst, R. J., W. J. Fisher, J. K. S. Tweed, and R. J. Wilkins. 2003. Comparison of grass and legume silages for milk production. 1. Production responses with different levels of concentrate. J. Dairy Sci. 86:2598-2611.

Dewhurst, R. J., A. M. Mitton, N. W. Offer, and C. Thomas. 1996. Effects of the composition of grass silages on milk production and nitrogen utilization by dairy cows. Anim. Sci. 62:25-34.

Dewhurst, R. J., J. M. Moorby, M. S. Dhanoa, R. T. Evans, and W. J. Fisher. 2000. Effects of altering energy and protein supply to dairy cows during the dry period. 1. Intake, body condition, and milk production. J. Dairy Sci. 83:1782-1794.

Huhtanen, P., J. I. Nousiainen, M. Rinne, K. Kytölä, and H. Khalili. 2008. Utilization and partition of dietary nitrogen in dairy cows fed grass silage-based diets. J. Dairy Sci. 91:3589-3599.

Kebreab, E., J. France, D. E. Beever, and A. R. Castillo. 2001. Nitrogen pollution by dairy cows and its mitigation by dietary manipulation. Nutr. Cycl. Agroecosyst. 60:275-285.

Khorasani, G. R., P. E. Jedel, J. H. Helm, and J. J. Kennelly. 1997. Influence of stage of maturity on yield components and chemical composition of cereal grain silages. Can. J. Anim. Sci. 77:259267.

Khorasani, G. R., E. K. Okine, J. J. Kennelly, and J. H. Helm. 1993. Effect of whole crop cereal grain silage substituted for alfalfa silage on performance of lactating dairy cows. J. Dairy Sci. 76:35363546.

Kirkland, R. M., and D. C. Patterson. 2006. The effect of quality of grass and maize silage on the intake and performance of beef cattle. Livest. Sci. 100:179-188.

Ledgard, S. F. 1989. Nutrition, moisture and rhizobial strain influence isotopic fractionation during $\mathrm{N}_{2}$, fixation in pasture legumes. Soil Biol. Biochem. 21:65-68.

MacRae, J. C., A. Walker, D. Brown, and G. E. Lobley. 1993. Accretion of total and individual amino acids by organs and tissues of growing lambs and the ability of nitrogen balance techniques to quantitate protein retention. Anim. Prod. 57:237-245.

Maeng, W. J., and R. L. Baldwin. 1976. Factors influencing rumen microbial growth rates and yields: Effect of amino acid additions to a purified diet with nitrogen from urea. J. Dairy Sci. 59:648-655.

McDonald, P., A. R. Henderson, and S. J. E. Heron. 1991. The Biochemistry of Silage. 2nd ed. Chalcombe Publications, Marlow, UK.

Nousiainen, J., K. J. Shingfield, and P. Huhtanen. 2004. Evaluation of milk urea nitrogen as a diagnostic of protein feeding. J. Dairy Sci. $87: 386-398$.
Ouellet, D. R., M. Demers, G. Zuur, G. E. Lobley, J. R. Seoane, J. V. Nolan, and H. Lapierre. 2002. Effect of dietary fiber on endogenous nitrogen flows in lactating dairy cows. J. Dairy Sci. 85:3013-3025.

Pfeffer, E., and A. Hristov. 2005. Nitrogen and Phosphorus Nutrition of Cattle. CABI Publishing, Wallingford, UK.

Schwertl, M., K. Auerswald, R. Schäufele, and H. Schnyder. 2005. Carbon and nitrogen stable isotope composition of hair: Ecological footprints of production systems? Agric. Ecosyst. Environ. 109:153-165.

Sick, H., N. Roos, E. Saggau, K. Haas, V. Meyn, B. Walch, and N. Trugo. 1997. Amino acid utilisation and isotope discrimination of amino nitrogen in nitrogen metabolism in rat liver in vivo. Eitschr. Ernahrungs. 36:340-346.

Spanghero, M., and Z. M. Kowalski. 1997. Critical analysis of $\mathrm{N}$ balance experiments with lactating cows. Livest. Prod. Sci. 52:113122

Sponheimer, M., T. Robinson, L. Ayliffe, B. Roeder, J. Hammer, B. Passey, A. West, T. Cerling, D. Dearing, and J. Ehleringer. 2003. Nitrogen isotopes in mammalian herbivores: Hair $\delta^{15} \mathrm{~N}$ values from a controlled feeding study. Int. J. Osteoarchaeol. 13:80-87.

Sutoh, M., Y. Obara, and T. Yoneyama. 1987. Variations of natural abundances in the tissues and digesta of domestic animals. Radioisotopes 36:74-77.

Sutton, J. D. 1989. Altering milk composition by feeding. J. Dairy Sci. 72:2801-2814.

Tamminga, S., H. Schulze, J. Van Bruchem, and J. Huisman. 1995. The nutritional significance of endogenous N-losses along the gastro-intestinal tract of farm animals. Arch. Tierernahr. 48:9-22.

Tas, B. M., and A. Susenbeth. 2007. Urinary purine derivative excretion as an indicator of in vivo microbial $\mathrm{N}$ flow in cattle: A review. Livest. Sci. 111:181-192.

Wallsten, J., J. Bertilsson, E. Nadeau, and K. Martinsson. 2010. Digestibility of whole-crop barley and oat silages in dairy heifers. Animal 4:432-438.

Wattiaux, M. A., and K. L. Karg. 2004. Protein level for alfalfa and corn silage based diets: I. Lactational response and milk urea nitrogen. J. Dairy Sci. 87:3480-3491.

Wattiaux, M. A., and J. D. Reed. 1995. Fractionation of nitrogen isotopes by mixed ruminal bacteria. J. Anim. Sci. 73:257-266.

White, L. M. 1973. Carbohydrate reserves of grasses: A review. J. Range Manage. 26:13-18.

Wilson, G. F., D. D. S. MacKenzie, I. M. Brookes, and G. L. Lyon. 1988. Importance of body tissue as sources of nutrients for milk synthesis in the cow, using ${ }^{13} \mathrm{C}$ as a marker. Br. J. Nutr. 60:605617.

Yoneyama, T., Y. Ohta, and T. Ohtani. 1983. Variations of natural ${ }^{13} \mathrm{C}$ and ${ }^{15} \mathrm{~N}$ abundances in the rat tissues and their correlation. Radioisotopes 32:330-332. 